University of Nebraska - Lincoln

DigitalCommons@University of Nebraska - Lincoln

Publications from USDA-ARS / UNL Faculty

U.S. Department of Agriculture: Agricultural

Research Service, Lincoln, Nebraska

2012

\title{
Biofuel production from water hyacinth in the Pantanal wetland
}

\author{
Ivan Bergier \\ Laboratory of Biomass Conversion, ivan@cpap.embrapa.br \\ Suzana M. Salis \\ Laboratory of Biomass Conversion \\ César H.B. Miranda \\ University of Nebraska-Lincoln \\ Enrique Ortega \\ State University of Campinas \\ Carlos A. Luengo \\ State University of Campinas
}

Follow this and additional works at: https://digitalcommons.unl.edu/usdaarsfacpub

Bergier, Ivan; Salis, Suzana M.; Miranda, César H.B.; Ortega, Enrique; and Luengo, Carlos A., "Biofuel production from water hyacinth in the Pantanal wetland" (2012). Publications from USDA-ARS / UNL Faculty. 1142.

https://digitalcommons.unl.edu/usdaarsfacpub/1142

This Article is brought to you for free and open access by the U.S. Department of Agriculture: Agricultural Research Service, Lincoln, Nebraska at DigitalCommons@University of Nebraska - Lincoln. It has been accepted for inclusion in Publications from USDA-ARS / UNL Faculty by an authorized administrator of DigitalCommons@University of Nebraska - Lincoln. 


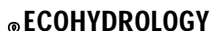

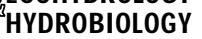

DOI: 10.2478/v10104-011-0041-4

Vol. 12

No. $1,77-84$

2012

\section{Biofuel production from water hyacinth in the Pantanal wetland}

\author{
Ivan Bergier ${ }^{1 *}$, Suzana M. Salis ${ }^{1}$, César H.B. Miranda ${ }^{2}$, \\ Enrique Ortega ${ }^{3}$, Carlos A. Luengo ${ }^{4}$ \\ ${ }^{1}$ Laboratory of Biomass Conversion, Embrapa Pantanal, CPAP, P.O.109, \\ Corumbá-MS, Brazil \\ ${ }^{*}$ Corresponding author's e-mail address: ivan@cpap.embrapa.br \\ ${ }^{2}$ Embrapa Labex-USA \& Bioenergy ARS-USDA Grass, Forage \& Bioenergy Research \\ Unit, 215 Biochemistry Hall, University of Nebraska, Lincoln, NE 68583-0737 \\ ${ }^{3}$ Laboratory of Ecological Engineering and Applied Informatics, State University \\ of Campinas, FEA, P.O. 6121, Campinas-SP, Brazil \\ ${ }^{4}$ Laboratory of Alternative Fuels, State University of Campinas, IF, P.O. 6165, \\ Campinas-SP, Brazil
}

\begin{abstract}
The Pantanal is a major wetland in the inner South America, with the potential for production of large quantities of biomass of aquatic floating species, especially water hyacinth (Eicchornia crassipes and E. azurea), during the aquatic phase of the floodpulse characteristic for this ecosystem. Such biomass could be wisely managed for the production of biofuels. This should be based on the concepts of renewability and ecosystem surplus, and could help in neutralizing of regional and global industrial carbon impacts and to induce socioeconomic development. The aquatic biomass exploitation would require low fossil energy and materials inputs, leaving a positive energy balance, with minimal interference in the environment. This emerging biofuel-based economy in the Pantanal can be a good example of human adaptation to climatic changes by managing carbon export of natural wetlands. The concepts described herein could be used in other natural, restored or artificially constructed wetlands.
\end{abstract}

Key words: bioenergy, aquatic biomass, climatic change, ecosystem surplus, renewability.

\section{Introduction}

The renewable processes of transferring materials and energy in ecosystems are ubiquitous. While the solar energy flows in a single direction, chemical elements are continuously recombined by ecosystems to maintain their structure and function. In ecosystem thermodynamics, it is necessary to consider the amount of solar energy spent to make goods or services, both directly or indirectly (O’Neill et al. 2006). Therefore, it is necessary to characterize the renewability of a given source, as a measure of fast turnover or non-fossil energy and materials effectively employed in the productive chain of a given product (Muller 2007). Moreover, the management of ecosystems for food and en- 
ergy products needs to rely on the concept of the ecosystem surplus, such as the concept of human appropriation of net primary production (HANPP) discussed by O'Neill et al. (2006). Basically, it means that there must be an exploitable threshold in which a renewable and sustainable resource can be removed from the ecosystem without affecting its structural and functional integrities (i.e. maintains its ecosystem resilience). It can also be viewed as the amount of pristine ecosystem resources that can be used for human needs that would otherwise inexorably and quickly undergo biogenic gas releases to the atmosphere.

In this review we discuss the potential usage of aquatic biomass (water hyacinth) produced in the Pantanal in the light of the concepts previously discussed consonant to the principles of Ecohydrology, as set forth in Zalewski (2002a, 2002b).

\section{Material and methods}

This review is based on published data regarding the Pantanal wetland ecosystem structure, functionality and hydrology-climate-human forcing dynamics. Thereafter information on floating biomass production and riverine exportation is compiled to derive a first order estimation of the potential and sustainable biomass useful for biofuel production in terms of life cycle analysis (LCA) and HANPP. Finally, detailed published information on the main species of water hyacinth, Eicchornia crassipes, is used to estimate biofuel potentials according to chemical and physical characteristics of its biomass and water content.

\section{Results and discussion}

\subsection{Description of the Pantanal wetland}

The Pantanal is a major tropical wetland in the inner South America (Fig. 1). Its peculiar geomorphologic aspects were addressed by Assine (2005), while human threats and hydrologic features are very well documented by Junk and Cunha (2005). The extraordinary productivity and biodiversity is largely stimulated by the annual flood-pulse that provides water and materials for photosynthesis and other complex metabolic routes (Junk et al. 1989). The water balance in the floodplain is usually negative, since evapotranspiration exceeds rainfall in about $400 \mathrm{~mm}$ every year. The flood-pulse slowly flows like a "soliton wave" from the rainy north and northeastern uplands (Cerrado and Amazon ecotones) to southern floodplains of the Upper Paraguay River Basin (Fig. 1). Due to the large distance from densely urbanized areas and the difficulty to exploit the wetland with petroleum energy and materials, Pantanal ecosystems has been conserved rather unaltered since the earlier occupation by Iberian Europeans. Recent anthropogenic threats are the social (cultural and educational)

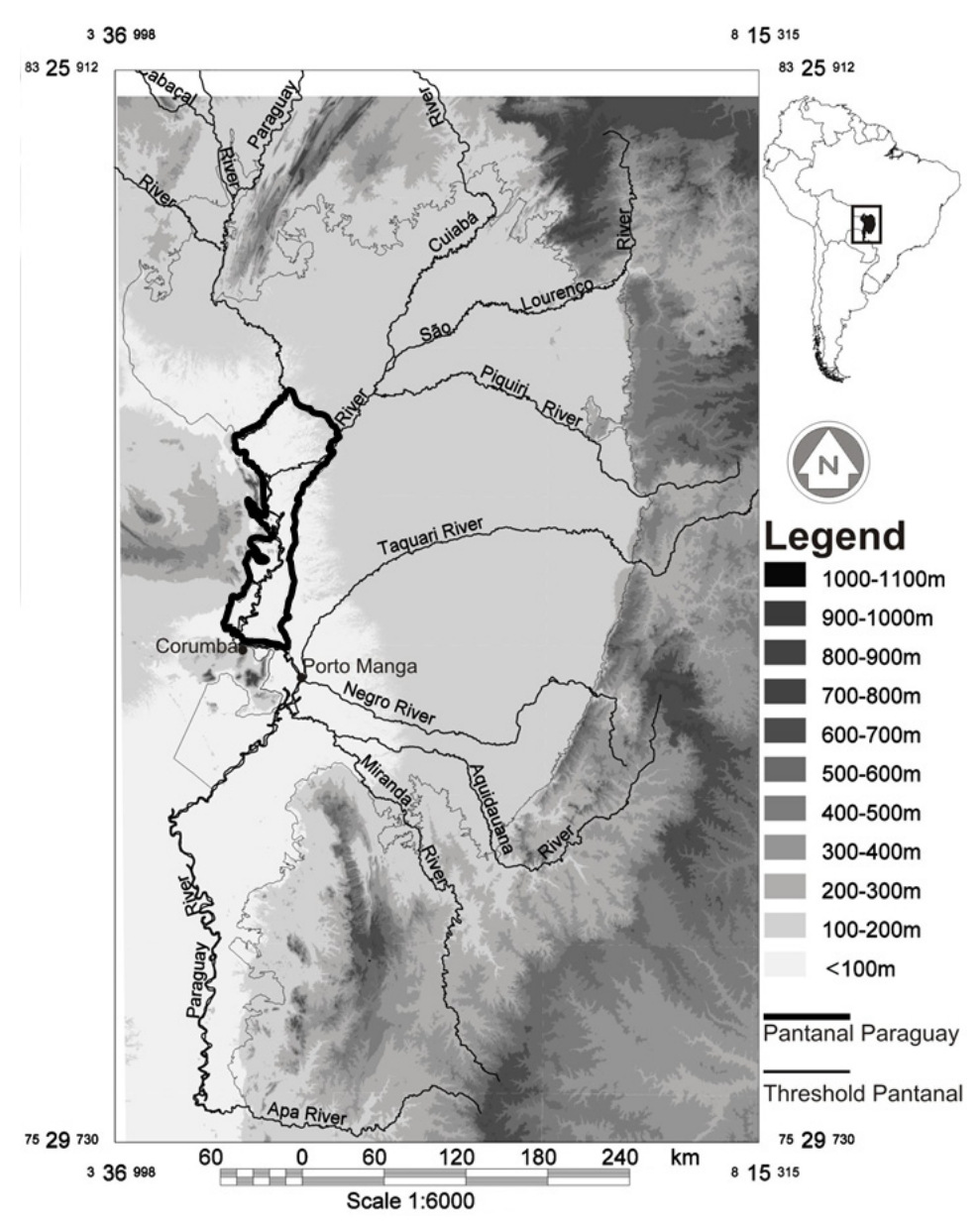

Fig. 1. Spatially interpolated digital elevation model (DEM) in m.a.s.1. highlighting the Paraguay River floodplain (lighter area) in the Brazilian Pantanal (thin black contour) in South America. Note the location of the city of Corumbá and Porto da Manga in the Paraguay River. The $\sim 8000 \mathrm{~km}^{2}$ subregion called "Pantanal of Paraguay" is delimited by a thick black contour. 90-m spatial resolution DEM in UTM coordinates was obtained from the Shuttle Radar Topography Mission (SRTM, http://www2.jpl.nasa.gov/srtm). Interpolation made in SPRING GIS (http://www.dpi.inpe.br). 
degradation, extreme climate events, upland landuse changes resulting in water and soil degradation (small hydroelectric dams and agriculture based on petroleum inputs), and hydrologic-geomorphologic engineering to recover enduring flooded lands in the Taquari river basin or to improve navigation in the main stem of the Paraguay River.

Most of the rural economy in the Pantanal floodplain is based on extensive cattle raising, but ranchers use very little fossil energy and materials for pasture growth, being largely reliant on the natural flood-pulse. The rising water phase of the flooding provides water and nutrients to the autotrophic growth of native pastures around the floodplain. Without human/cattle intervention this biomass is only partially grazed and incorporated to the micro and macro terrestrial fauna or burnt in lightninginduced wildfires, which would return large fraction of the assimilated carbon to the atmosphere in the form of biogenic or pyrogenic trace gases. Naturally, part of it is used by heterotrophic aquatic bacteria in the following water phase, being incorporated to the aquatic biota, retained in freshwater sediments, or transferred downstream to the Atlantic Ocean, where it would settle or be returned to the atmosphere in the form of biogenic gases.

In general, it can be said that this traditional human/cattle intervention in the Pantanal floodplain for beef production is somewhat renewable and sustainable because there is neither significant use of fossil energy and materials nor significant interference in the flood-pulse dynamics and general ecosystem services. There are punctual negative aspects if we consider the small social progress due to people isolation, the eventual clearing of native non-flooding areas for exotic pasture cultivation, and enteric methane emissions from the cattle. Social concerns can be controlled by public policies in telecommunication, and the environmental issues by a better monitoring of this ecosystem. In general, compared to "business as usual" beef farms in other areas, traditional beef production in Pantanal wetland is more likely based on the ecosystem surplus due to the flood-pulse, maintaining biodiversity and wisely using ecosystem services.

Climate change scenarios based on twelve Global Climate Models suggest that the Pantanal will experience an increase in water availability up to the second half of the $21^{\text {st }}$ century. The La Plata Basin runoff may increase in $10-40 \%$ by 2050 (Milly et al. 2005). Actual observations corroborate these scenarios, although it is expected the concomitantly occurrence of extremely wet or dry events. The analysis of secular daily river-level registers made by the Brazilian Navy indicates a wetter Pantanal since 1974 (Bergier et al. 2008) with only three dryer events in 2001, 2005 and 2009. By the mid
1970, rainfall and river flow (level) increased in the whole La Plata Basin (Liebmann et al. 2004; Dai et al. 2009). Thus model scenarios and observed data suggest that in Pantanal, particularly in the Paraguay River floodplain, social and economic development can reasonably rely on floodplain water in this century, though considering the increase of eventual extremes of very dry and very wet years.

\subsection{Sustainable biofuel production in the Pantanal wetland: global and regional perspectives}

The replacement of petroleum by renewable energy from ecosystems and agroecosystems represents a central strategy to mitigate and to adapt to climate changes. It is known that monocultures based on great inputs of fertilizers, pesticides and herbicides derived from petroleum may not be properly renewable (Muller 2007). On the other hand, the aquatic biomass of pristine (also restored and constructed) wetlands might be a promising resource for second generation biofuels that assures the tripod renewability, sustainability and ecosystem surplus.

Floodplains are placed along with the most productive and diversified ecosystems. Biomass production annually adapts to the changing ecotone according to the duration and strength of the floodpulse. Over the dry period terrestrial grasses develop preferably, while aquatic plants thrive in the wet season. In the aquatic phase of the flood-pulse the production of floating species increases, especially Eicchornia crassipes and E. azurea (Pott, Pott 2000; see also Fig. 2) that are commonly known as water hyacinth. Assuming the occurrence of adequate aquatic environments in about $50 \%$ of the $8000 \mathrm{~km}^{2}$ of the Brazilian Paraguay river floodplain (see the area delimited by the black contour line in Fig. 1), the annual water hyacinth production may reach about 0.8 to $2.4 \times 10^{7}$ tons $(\mathrm{Mg})$ of dry biomass, although unevenly distributed throughout the year. Based on weekly information of videographic data (Ivan Bergier, unpublished results), water hyacinth exported by the riverine ecosystem of Pantanal is asymmetrically concentrated between March and July, nearly in phase with the dynamics of the flood-pulse (Fig. 4).

Preliminary collections in the river strait near Corumbá city indicate that the annual riverine exportation of this floating aquatic vegetation is roughly $1.7 \times 10^{6}$ tons of dry biomass (Ramires 1993), corresponding to 7 to $21 \%$ of dry biomass of water hyacinth's total potential production in the Paraguay River floodplain (see Fig. 3). This comprises nearly $60 \%$ of the riverine carbon exportation of the floodplain, with the remaining $40 \%$ as organic and inorganic dissolved and particulate 
carbon (Ramires 1993). Considering a carbon fraction of about $38 \%$ in water hyacinth (Table I), its exportation by the Paraguay River may represent about $1 \%$ of the net ecosystem production taking place in Pantanal. This is much lower than the 20$-25 \%$ of the mean global HANPP (O'Neill et al. 2006), which makes riverine-exported biomass of water hyacinth environmentally sound to use as a source for biofuels. We also can consider other ecological and socioeconomic beneficial aspects of using the ecosystem surplus of water hyacinth for such a purpose, such as i) the non-food nature of

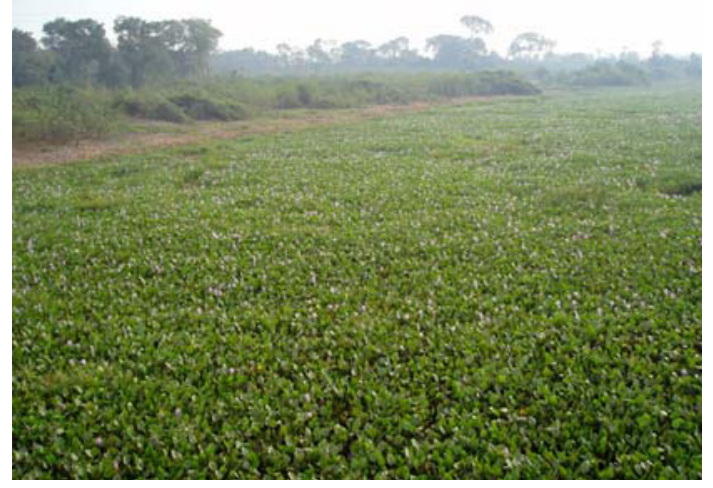

Fig. 2. A small tributary of the Paraguay River fully clogged by flourishing water hyacinth, near Porto da Manga, Mato Grosso do Sul State, Brazil. Image credit, Ivan Bergier (May 8, 2009). the biomass; ii) its use does not involve land-use changes or agroecosystems changes for biofuel crops; iii) its potential low economic and energetic cost and its potential for being harvested at a few collecting points on the river for biomass processing; and iv) the potential benefits for the downstream ecosystem health from the periodic water hyacinth extraction (Saha-Das, Jana 2003). These factors indicate the potential value for a biofuels economy in the Pantanal based on water hyacinth. It would combine ecosystem surplus and social inclusion through the creation of direct and indirect jobs,

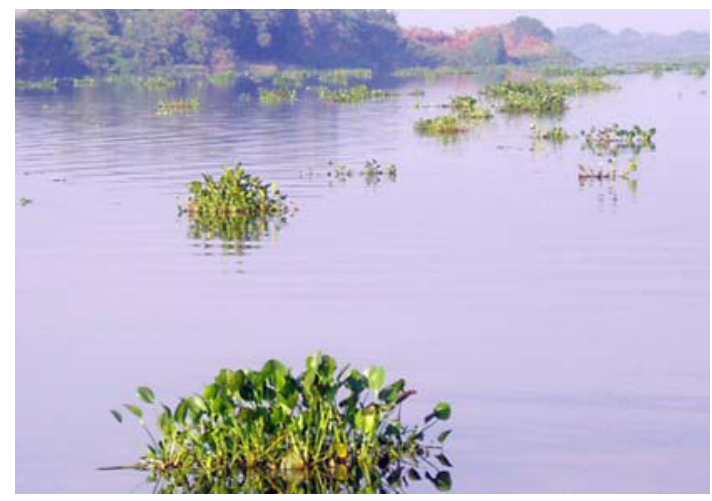

Fig. 3. Floating mats of water hyacinth, a promising source of wetland biofuels, carried out by the Paraguay River in Porto da Manga. Image credit, Ivan Bergier (May 8, 2009).

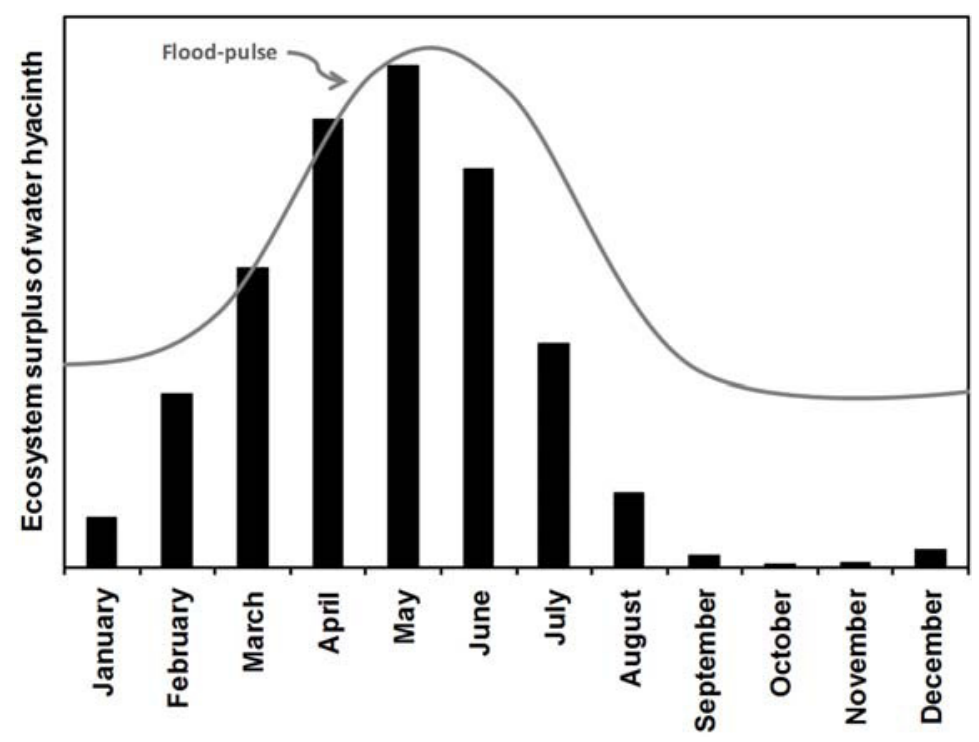

Fig. 4. Theoretical exportation (ecosystem surplus) of water hyacinth based on weekly video data and its phase correspondence with the Pantanal flood-pulse (surplus unity is arbitrary, though the year integration may exceed a million metric ton of dry biomass). A sample of 1-hr video (two frames per minute) of water hyacinth islands flowing in the Paraguay River in March 23, 2008 (Corumbá, see Fig. 1) is available at http://www.youtube.com/ user/Ivaberg/videos. 
Table I. Water content, chemical and structural compositions of water hyacinth biomass.

\begin{tabular}{l|c|c|c|l}
\hline & Lower limit & Upper limit & Central value & Reference \\
\hline \multicolumn{5}{c}{ Water content (\%) } \\
\hline $\mathrm{w}$ & 85 & 95 & 90 & This study \\
\hline \multicolumn{5}{c}{ Dry Matter (\%) } \\
Cellulose & 18 & 31 & 24 & Bolenz et al. 1990; Chanakya et al. 1993 \\
Hemicellulose & 18 & 43 & 30 & Poddar et al. 1991; Patel 1993 \\
Lignin & 7 & 26 & 16 & Bolenz et al. 1990; Chanakya et al. 1993 \\
Ashes & 15 & 26 & 20 & Bolenz et al. 1990; Abdelhamid, Gabr 1991 \\
\hline \multicolumn{5}{c}{ Elemental composition (\%) } \\
\hline $\mathrm{C}$ & 33 & 43.3 & 38.4 & \\
$\mathrm{H}$ & 5.3 & 6.4 & 5.85 & \\
$\mathrm{O}$ & 27.5 & 28.8 & 28.1 & \\
$\mathrm{~N}$ & 1.5 & 4.3 & 2.9 & \\
$\mathrm{~S}$ & 0.35 & 0.59 & 0.47 & Chynoweth et al. 1981; Matsumura 2002 \\
$\mathrm{P}$ & 0.7 & 0.84 & 0.77 & \\
$\mathrm{~K}$ & 2.75 & 2.8 & 2.78 & \\
$\mathrm{Ca}$ & 0.95 & 1.68 & 1.32 & \\
$\mathrm{Na}$ & 0.88 & 2 & 1.44 & \\
\hline
\end{tabular}

leading to economic profitability based on renewability and sustainability.

\subsection{Eicchornia crassipes: characteristics and potential biofuel production}

Native to Brazil, but dispersed in all five continents, water hyacinth has become a serious environmental issue due to its high (vegetative and sexual) reproduction rate and dispersion (NAS 1976; Gopal 1987; Wilson et al. 2005; Téllez et al. 2008). Alternatively, the high reproduction rate, nutrient uptake, and biomass yields made water hyacinth an interesting solution for wastewater treatment and biogas production (NAS 1976, Gunnarsson, Petersen 2007; Malik 2007). A comparison of dry biomass productivity of water hyacinth and other plants is shown in Fig. 5. Data on water content, dry weight and chemical and structural compositions of water hyacinth are listed in Table I.

At present, second generation biofuels produced by pyrolysis (Mesa-Pérez et al. 2005; Boateng et al. 2007) and gasification (Higman, Burgt 2008) would be a promising approach for use of water hyacinth. Pyrolysis main products are bio-oil and biochar (Lehmann 2007), whereas the main target of gasification is syngas, a gas mixture of hydrogen and carbon monoxide used in Fischer-Tropsch (FT) process with catalysts to synthesize hydrocarbons such as gasoline or diesel. Biochar can be a potential carbon sink in soils (Lehmann 2007), while enhancing soil characteristics for a more sustainable agriculture (McHenry 2009).

Biomass-to-liquids (BTL) technologies (which does not demand significant changes in motor en- gines) based on water hyacinth may substantially increase the portfolio of available biomass resources. The higher heating value (HHV in $\mathrm{kJ} / \mathrm{kg}$ ) and the lower heating value ( $\mathrm{LHV}$ in $\mathrm{kJ} / \mathrm{kg}$ ) of water hyacinth can be derived by:

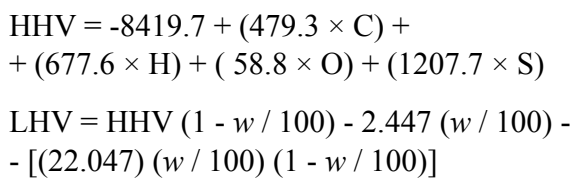

Assuming the calculated central values of $\mathrm{C}$, $\mathrm{H}, \mathrm{O}, \mathrm{S}$, and $w$ given in Table $\mathrm{I}$, the LHV of the wet biomass of water hyacinth might be roughly $1.6 \mathrm{MJ} / \mathrm{kg}$, which is very low when compared to reasonably dryer crop residues and forestry biomass resources. Therefore, despite of its high biomass yields (Fig. 5), water hyacinth may need to be treated with heat for BTL processing. Solving this issue by recovering heat from pyrolysis, gasification or solar heaters (remembering that solar energy is plenty accessible in tropical wetlands areas), water hyacinth viability can be substantially enlarged not only for FT synthesis but also for cellulosic ethanol (Nigam 2002; Mishima et al. 2008; Hronich et al. 2008; Sukumaran et al. 2009; Chandel et al. 2011).

Water hyacinth has also been envisaged as a promising source of hydrogen (which demands substantial changes in motor engines), which LHV is $125 \mathrm{MJ} / \mathrm{kg}$. Water hyacinth biomass can be gasified in supercritical water (pressure over 221 bars), producing a balanced gas mixture of hydrogen and carbon dioxide, and an aqueous solution rich in minerals. Molecular sieve filters can be used to segregate hydrogen molecules from carbon dioxide 


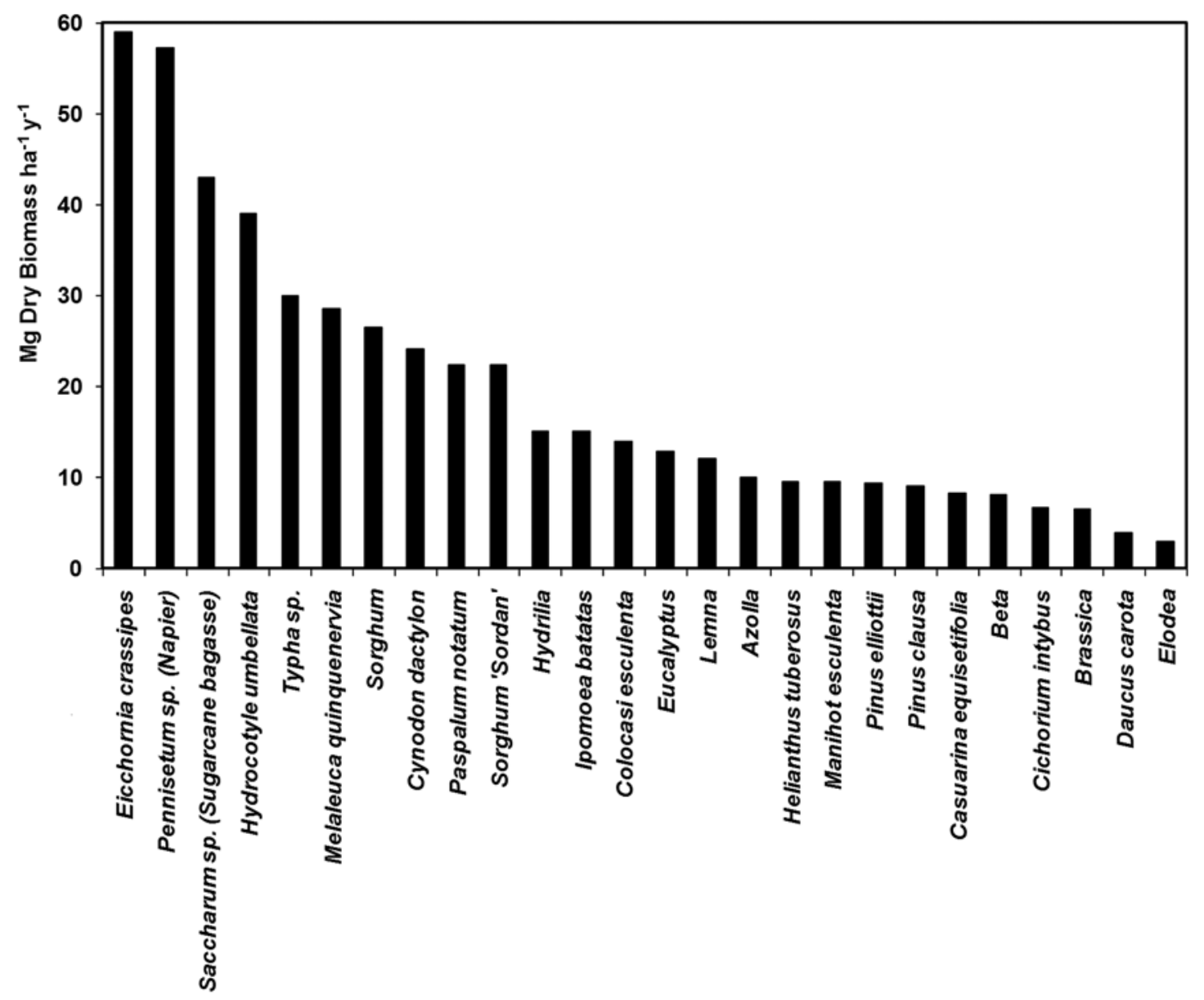

Fig. 5. Productivity of water hyacinth (Eicchornia crassipes) in comparison to other vegetal species and genera. Adapted from Duke (1983).

and water vapor in the gas mixture to achieve highenergy gas yields (Matsumura 2002; Mozaffarian et al. 2004; Matsumura et al. 2005).

The advantages of using the natural surplus of water hyacinth for biofuels is better seen when the whole productive chain is considered in the context of life cycle analysis - LCA (Muller 2007). Economic and environmental viability derives essentially from the used fraction of fossil energy and materials. The larger the fossil resources employed for biofuels production, the lesser is the whole efficiency (Delucchi 2006; Gallagher 2008). In the case of pristine, restored or constructed floodplains, the ecosystem surplus in the form of water hyacinth is naturally transported downstream by the riverine system, avoiding petroleum and machinery involved in biomass yield cropping. Thus in terms of LCA, the use of Pantanal wetland ecosystem biomass surplus of water hyacinth is appropriate due to i) minor energy investment for cropping (the riverine system does the assembly and transportation work); and ii) little trace gas emission footprints for biomass cropping and processing (mitigation of land-use and fossil trace gas emissions for energy, pesticides, herbicides and fertilizers). Moreover, it is likely that only $1 \%$ of the annual net ecosystem production is transported by the Paraguay River as water hyacinth. Assuming conservatively that a significant amount of this material would biogenically result in methane emissions, its use as biofuels would simply be a better use for a common atmospheric emission of biogenic methane.

\section{Concluding remarks}

In the Pantanal, the usage of naturally exported water hyacinth biomass for biofuels relies on the annual flood dynamics. The ecosystem surplus of water hyacinth biomass exported by the Pantanal wetland is sustainable and renewable, and can be a good source of biomass for biofuels production, regarding climatic change scenarios. More studies shall be carried out for a detailed characterization 
on the structure and functionality of floating mats exported by riverine ecosystems. The greater the understanding on this floating mats the better and more sustainable will be its biomass-to-biofuels conversion. To generally satisfy the concept of ecosystem surplus, it demands scrutinizing hydrological, ecological and biogeochemical processes to define a reasonable water hyacinth exploitation threshold for retaining basic ecosystem services. Biofuels from water hyacinth produced in restored or constructed wetlands may also be recognized as a replicable example of mitigation and adaptation strategies to cope with the progression of regional and global environmental changes and the high cost or depletion of petroleum in the near future.

\section{Acknowledgements}

This work was partially funded by the Project "Biofuel production from floating biomass mats in Brazilian floodplains: a case study in Pantanal" (MCT/CNPq/CT-Energ52-2008, 578084/20082 and EMBRAPA Macroprograma 2 Infoseg 02.09.00.015.00.00).

\section{References}

Abdelhamid, A.M., Gabr, A.A. 1991. Evaluation of water hyacinth as a feed for ruminants. Archiv Fur Tierernahrung-Archives of Animal Nutrition 41, 745-756.

Assine, M.L. 2005. River avulsions on the Taquari megafan, Pantanal wetland, Brazil. Geomorphology 70, 357-378.

Bergier, I., Ishii, I.H., Salis, S.M., Pellegrin, L.A., Resende, E.K., Tomas, W.M., Soares, M.T.S. 2008. Cenários de desenvolvimento sustentável no Pantanal em função de tendências hidroclimáticas. Série Documentos. Corumbá. MS. Embrapa Pantanal, p.1-21. Available via EMBRAPA. http://www.cpap.embrapa.br/publicacoes/online/DOC98.pdf. Accessed 11 May, 2010.

Boateng, A.A., Daugaard, D.E., Goldberg, N.M., Hicks, K.B. 2007. Bench-scale fluidized-bed pyrolysis of switchgrass for bio-oil production. Ind. Eng. Chem. Res. 46, 1891-1897.

Bolenz, S., Omran, H., Gierschner, K. 1990. Treatments of water hyacinth tissue to obtain useful products. Biological Wastes 33, 263-274.

Chanakya, H.N., Borgaonkar, S., Meena, G., Jagadish, K.S. 1993. Solid-phase biogas production with garbage or water hyacinth. Bioresour. Technol. 46, 227-231.

Chandel, A.K., Chandrasekhar, G., Radhika, K., Ravinder, R., Ravindra, P. 2011. Bioconversion of pentose sugars into ethanol: A review and future directions. Biotech. Mol. Biol. Rev. 6, 8-20.

Chynoweth, D.P., Ghosh, S., Henry, M.P. 1981. Biogasification of blends of water hyacinth and domestic sludge. In: Proc. of the 1981 Internat. Gas Research Conf. Gas Research Institute, Los Angeles, CA, September 1981, pp. 742-755.
Dai, A., Qian, T., Trenberth K.E., Milliman, J.D. 2009. Changes in continental freshwater discharge from 1948-2004. J. Clim, doi: 10.1175/2008JCLI2592.1.

Delucchi, M.A. 2006. Life cycle analysis of biofuels. Draft Manuscript, Davis, CA, ITS, University of California at Davis. Available via UCDAVIS. http://www.its.ucdavis.edu/publications/2006/ UCD-ITS-RR-06-08.pdf. Accessed 11 May, 2010.

Duke, J.A. 1983. Handbook of energy crops. Unpublished. Available via PURDUE. http://www.hort.purdue. edu/newcrop/duke_energy/Eichornia_crassipes.html. Accessed 11 May, 2010.

Gallagher, E. 2008. The Gallagher review of the indirect effects of biofuels production. Renewable Fuels Agency, UK. Available via Renewable Fuels Agency. http://www.renewablefuelsagency.gov.uk/reportsandpublications/reviewoftheindirecteffectsofbiofuels. Accessed 11 May, 2010.

Gopal, B. 1987. Water hyacinth. Elsevier, Amsterdam. $471 \mathrm{pp}$.

Gunnarsson, C.C., Petersen, C.M. 2007. Water hyacinth as a resource in agriculture and energy production: a literature review. Waste Manag. 27, 117-129.

Higman, C., van der Burgt, M. 2008. Gasification. Elsevier, Amsterdam, 465 pp.

Hronich, J.E., Martin, L., Plawsky, J., Bungay, H.R. 2008. Potential of Eichhornia crassipes for biomass refining. J. Industrial Microbiol. Biotechnol. 35, 291-453.

Junk, W.J., Bayley, P.B., Sparks, R.E. 1989. The flood pulse concept in river-floodplain system. Can. Spec. Publ. Fish Quat. Sci. 106, 110-127.

Junk, W.J., Cunha, C.N. 2005. Pantanal: a large South American wetland at a crossroads. Ecological Engineer. 24, 391-401.

Lehmann, J. 2007. A handful of carbon. Nature 447, 143-144.

Liebmann, B., Vera, C.S., Carvalho, L.M.V., Camilloni, I.A., Hoerling, M.P., Allured, D., Barros, V.R., Baez, J., Bidegain, M. 2004. An observed trend in central South American precipitation. J. Clim. 17, 4357-4367.

Malik, A. 2007. Environmental challenge vis a vis opportunity: the case of water hyacinth. Environ. Internat. 33, 122-138.

Matsumura, Y. 2002. Evaluation of supercritical water gasification and biomethanation for wet biomass utilization in Japan. Energy Convers. Manag. 43, 1301-1310.

Matsumura, Y., Minowa, T., Potic, B., Kersten, S.R.A., Prins, W., van Swaaij, W.P.M., van de Beld, B., Elliott, D.C., Neuenschwander, G.G., Kruse, A., Antal Jr., M.J. 2005. Biomass gasification in near- and super-critical water: status and prospects. Biomass Bioenergy 29, 269-292.

McHenry, M.P. 2009. Agricultural bio-char production, renewable energy generation and farm carbon sequestration in Western Australia, Certainty, uncertainty and risk. Agriculture Ecosys. Environ. 129, 1-7.

Mesa-Pérez, J.M., Cortez, L.A.B., Rocha, J.D., Brodssard, L.E., Gomez, E.O. 2005. Unidimensional heat transfer analysis of elephant grass and sugar cane bagasse slow pyrolysis in a fixed bed reactor. Fuel Processing Technol. 86, 565-575. 
Milly, P.C.D., Dunne, K.A., Vecchia, A.V. 2005. Global pattern of trends in streamflow and water availability in a changing climate. Nature 438, 347-350.

Mishima, D., Kuniki, M., Sei, K., Soda, S., Ike, M., Fujita, M. 2008. Ethanol production from candidate energy crops, water hyacinth (Eichhornia crassipes) and water lettuce (Pistia stratiotes L.). Bioresour Technol 99, 2495-2500.

Mozaffarian, M., Deurwaarder, E.P., Kersten, S.R.A. 2004. Green gas (SNG) production by supercritical gasification of biomass. ECN-C-04-081 November 2004, 70 p. Available via BIOSNG. http://www.biosng. com/publications/reports. Accessed 11 May, 2010.

Muller, A. 2007. Sustainable agriculture and the production of biomass for energy use. Clim. Change, doi:10.1007/s10584-008-9501-2.

NAS 1976. Making aquatic weeds useful: some perspectives for developing countries. National Academy of Sciences, Washington. $175 \mathrm{pp}$.

Nigam, J.N. 2002. Bioconversion of water - hyacinth (Eichhornia crassipes) hemicellulose acid hydrolysate to motor fuel ethanol by xylose - fermenting yeast. J. Biotechnol. 97, 107-116.

O’Neill, D.W., Tyedmers, P.H., Beazley, K.F. 2006. Human appropriation of net primary production (HANPP) in Nova Scotia, Canada. Reg. Environ. Change 7, 1-14.

Patel, V., Desai, M., Madamwar, D. 1993. Thermochemical pretreatment of water hyacinth for improved biomethanation. Appl. Biochem. Biotechnol. 42, 67-74.

Poddar, K., Mandal, L., Banerjee, G.C. 1991. Studies on water hyacinth (Eichhornia crassipes) chemical composition of the plant and water from different habitats. Indian Vet. J. 68, 833-837.
Pott, V.J., Pott, A. 2000. Plantas aquáticas do Pantanal. Brasília, Embrapa. 368 pp.

Ramires, J.R.S. 1993. Transporte de banco de macrófitas flutuantes em função do nível hidrométrico no Rio Paraguai, Pantanal-MS [Floating macrophyte mats transport as a function of the Paraguay River level, Pantanal-MS]. Monograph in Biological Sciences, Federal University of Mato Grosso do Sul, UFMS, Corumbá, Mato Grosso do Sul State, Brazil. 31 pp.

Saha-Das, S., Jana, B.B. 2003. Fish-macrophyte association as a low-cost strategy for wastewater reclamation. Ecol. Eng. 21, 21-41.

Sukumaran, R.K., Singhania, R.R., Mathew, G.M., Pandey, A. 2009. Cellulase production using biomass feed stock and its application in lignocellulose saccharification for bio-ethanol production. Renewable Energy 34, 421-424.

Téllez, T.R., López, E.M.R., Granado, G.L., Pérez, E.A., López R.M., Guzmán, J.M.S. 2008. The water hyacinth, Eichhornia crassipes: an invasive plant in the Guadiana River Basin (Spain). Aquatic Invasions 3, 42-53.

Wilson, J.R., Holst, N., Rees, M. 2005. Determinants and patterns of population growth in water hyacinth. Aquatic Botany 81, 51-67.

Zalewski, M. 2002a. Ecohydrology - the use of ecological and hydrological processes for sustainable management of water resources. Hydrological Sci. 47, 823-832.

Zalewski, M. 2002b. Guidelines for the integrated management of the watershed - Phytotechnology and Ecohydrology. UNEP, Freshwater Management Series No. 5. 188 pp. 